\title{
Effect of Rumen-Degradable Protein Balance and Forage Type on Bulk Milk Urea Concentration and Emission of Ammonia from Dairy Cow Houses
}

\author{
G. van Duinkerken, ${ }^{1}$ G. André, ${ }^{1}$ M. C. J. Smits, ${ }^{2}$ G. J. Monteny, ${ }^{2}$ and L. B. J. Šebek ${ }^{1}$ \\ ${ }^{1}$ Animal Sciences Group, Applied Research, and \\ ${ }^{2}$ Agrotechnology and Food Innovations, Agrisystems and Environment \\ Wageningen University and Research Center, Wageningen, the Netherlands
}

\begin{abstract}
As the Dutch government and dairy farming sector have given priority to reducing ammonia emission, the effect of diet on the ammonia emission from dairy cow barns was studied. In addition, the usefulness of milk urea content as an indicator of emission reduction was evaluated. An experiment was carried out with a herd of 55 to 57 Holstein-Friesian dairy cows housed in a naturally ventilated barn with cubicles and a slatted floor. The experiment was designed as a $3 \times 3$ factorial trial and repeated 3 times. During the experiment, cows were confined to the barn (no grazing) and were fed ensiled forages and additional concentrates. The default forage was grass silage. The nutritional experimental factors were: (1) rumen-degradable protein balance of the ration for lactating cows with 3 levels (0, 500 , and $1000 \mathrm{~g} / \mathrm{cow}$ per d), and (2) proportion of corn silage in the forage ration for lactating cows with 3 levels $(0,50$, and $100 \%)$ of forage dry matter intake. Several series of dynamic regression models were fitted. One of these models explained emission of ammonia by the nutritional factors and the temperature; another model explained ammonia emission by the bulk milk urea content and the temperature. The ammonia emission from the barn increased when levels of rumendegradable protein balance increased. Furthermore, at a given level of rumen-degradable protein balance, the emission of ammonia correlated positively with the corn silage content in the forage ration. However, this correlation was not causal, but was the result of interaction between corn silage proportion and intake of ileal digestible protein. The bulk milk urea content and the temperature correlated strongly with the ammonia emission from the barn; the selected model accounted for $76 \%$ of the variance in emission. It was concluded
\end{abstract}

Received March 1, 2004.

Accepted November 29, 2004.

Corresponding author: Gert van Duinkerken; e-mail: gert. vanduinkerken@wur.nl. that the emission of ammonia from naturally ventilated dairy cow barns was strongly influenced by diet. The emission can be reduced approximately $50 \%$ by reducing the rumen-degradable protein balance of the ration from 1000 to $0 \mathrm{~g} / \mathrm{cow}$ per $\mathrm{d}$. The milk urea content is a good indicator of emission reduction.

(Key words: ammonia emission, milk urea, rumendegradable protein balance)

Abbreviation key: DVE = true protein digested in the small intestine according to Dutch standards, $\mathbf{G}=100 \%$ grass silage, $\mathbf{G M}=50 \%$ grass silage $/ 50 \%$ corn silage, $\mathbf{M}=100 \%$ corn silage, $\mathbf{O E B}=$ rumen-degradable protein balance according to Dutch standards, RDPB = rumen-degradable protein balance, VEM $=\mathrm{NE}_{\mathrm{L}}$ according to Dutch standards.

\section{INTRODUCTION}

Emission of ammonia $\left(\mathrm{NH}_{3}\right)$ is a main cause of environmental eutrophication and acidification. To minimize environmental damage related to $\mathrm{NH}_{3}$ emission, the Dutch government aims to reduce the level of calculated $\mathrm{NH}_{3}$ emission from 216 kilotons in 1980 to 128 kilotons in 2004 (van der Hoek, 2000), and 100 kilotons in 2010 (Sliggers, 2000). In the Netherlands, dairy cattle production is responsible for half of the total $\mathrm{NH}_{3}$ emission (LEI, 1999; Steenvoorden et al., 1999). Ammonia volatilizes mainly from dairy barns, from manure application on the field and, to a lesser extent, from outdoor manure storage facilities and during grazing. New techniques to apply manure and to cover storage facilities, currently enforced by law, have reduced $\mathrm{NH}_{3}$ emission from dairy cattle production (van der Hoek, 2000). However, to achieve a further reduction and to comply with future goals set by the Dutch government to protect ecosystems, $\mathrm{NH}_{3}$ emission from dairy barns must be reduced further. Emission of $\mathrm{NH}_{3}$ from the dairy barn depends on the cows' diet, the design of the barn, the outdoor and indoor climate, and the management of the farm, e.g., grazing regimen (Monteny, 2000). Urinary urea concentration appears to be an 
important predictor of $\mathrm{NH}_{3}$ emission from dairy barns (Elzing and Monteny, 1997; Monteny, 2000). Nutritional measures related to $\mathrm{NH}_{3}$ emission should focus on reduction of urinary urea concentration by lowering dietary $\mathrm{N}$ rather than by increasing urine volume (Smits et al., 1997). The $\mathrm{N}$ intake of dairy cows is strongly influenced by diet composition. In an earlier study, Smits et al. (1995) showed (in a forced ventilated building) the potential for reducing $\mathrm{NH}_{3}$ emissions by reducing the rumen-degradable protein surplus. Forced ventilation was necessary in that study because no method was available at that time to quantify the emission from naturally ventilated buildings. As well as the protein surplus in the diet, the type of roughage may play a part in $\mathrm{NH}_{3}$ emission. It may have an effect on the intake level, the nitrogen use, and the nitrogen excretion in feces and urine. It may also influence the concentration of excreted minerals due to surpluses of potassium and sodium in the diet that mainly determine the volume of urine. On typical dairy farms in the Netherlands, grass silage and corn silage are the main types of roughage, which are fed in varying proportions depending on the region and farm management. Therefore, in this paper, the effects of rumen-degradable protein balance (OEB; Dutch standard) and type of roughage are studied in a naturally ventilated cattle barn. A tool for monitoring the level of $\mathrm{NH}_{3}$ emission would be useful for farmers and for the government. From the known pathways of urea, it was hypothesized that bulk milk urea may be such an indicator. Its relation with $\mathrm{NH}_{3}$ emission was studied in this paper.

The $\mathrm{N}$ intake by dairy cows is reflected in the milk urea concentration within several hours. About $2 \mathrm{~h}$ after feed intake, an increased level of $\mathrm{NH}_{3}$ is detected in ruminal fluid (de Brabander et al., 1999a,b; van Vuuren, 1994; van Vuuren and Tamminga, 2001). After that, within 1.5 to $2.0 \mathrm{~h}$, a peak concentration is found in blood urea. Finally, milk urea equilibrates with blood urea with a lag time of 1 to $2 \mathrm{~h}$ (Gustafsson and Palmquist, 1993). In total, the average time between intake of diet $\mathrm{N}$ and milk urea peak is $5 \mathrm{~h}$. Urea is produced in the liver from $\mathrm{N}$-containing compounds such as $\mathrm{NH}_{3}$ and amino acids (van Straalen, 1995; Hof et al., 1997). These N-containing compounds are formed during ruminal fermentation and in the intermediate metabolism. During the process of protein breakdown in the rumen, ammonia is formed and available as substrate for synthesis of microbial protein in the rumen. Excess rumen-degradable protein is absorbed from the rumen and converted to urea by the liver (Hof et al., 1997). True protein digested in the small intestine is required for maintenance, milk protein synthesis, tissue protein synthesis, and replacement of endogenous nitrogen losses with efficiencies of $67,64,50$, and $67 \%$, respec- tively, when fed according to requirements (Tamminga et al., 1994). This efficiency is influenced by amino acid composition of the ileal digestible protein and decreases with suboptimal amino acid composition. The part of the ileal digestible protein that is not being used is deaminated into energy-providing components and $\mathrm{NH}_{3}$. Ammonia residues are converted into urea by the liver and excreted in the urine. With mobilization of muscle tissue, deamination of protein occurs (Hof et al., 1994; van Straalen, 1995). Part of the blood urea pool is excreted by urine and milk. Urinary urea excretion occurs after urea filtering by the kidneys. However, not all excreted urinary $\mathrm{N}$ is in the form of urea. Nitrogen is also excreted as purine derivatives (mostly allantoin) and creatinine, with purine derivatives originating mainly from catabolism of absorbed microbial nucleic acids (Gonda and Lindberg, 1994). The total urinary N excretion, together with $\mathrm{K}$ and $\mathrm{Na}$ excretion, determines the main urine volume (Bannink et al., 1999). Next to excretion of urea in urine and milk, urea is involved in nitrogen recycling in the rumen. Urea diffuses from blood into saliva and is brought into the rumen during eating and ruminating of the cow. Urea is also brought directly into the rumen by diffusion from blood. Such recycling concerns about 35 to $65 \mathrm{~g}$ of N/d, corresponding with an amount of 220 to $410 \mathrm{~g} / \mathrm{d}$ of rumen-degradable protein (van Vuuren and Tamminga, 2001). At low nitrogen intake, the renal mechanism will conserve urea in the body pool (Eriksson and Valtonen, 1982). Renal capacity may be overloaded when the entry rate of urea is very high. In the study of Mugerwa and Conrad (1971), the renal urea excretion leveled off at an NPN intake of $175 \mathrm{~g} / \mathrm{d}$. It was concluded from the excretion curve that the ability of the kidney to concentrate urea reached a physiological limit. Milk urea levels are highly correlated with blood urea levels (Oltner and Wiktorsson, 1983; Gonda and Lindberg, 1994; Meijer et al., 1996). Equilibration of urea levels in blood and milk is a result of diffusion of urea along mammary ducts and tubules and through the mucosa in the alveoli (Gustafsson and Palmquist, 1993). A minor factor influencing milk urea concentration is urea synthesis by the mammary gland (Mepham et al., 1982). Next to true protein (casein) and urea, milk contains minor concentrations of other $\mathrm{N}$ components like $\mathrm{NH}_{3}$, creatine, creatinine, uric acid, orotic acid, peptides, and hippuric acid (DePeters and Ferguson, 1992).

\section{MATERIALS AND METHODS}

The effect of diet on the $\mathrm{NH}_{3}$ emission from dairy cow barns was studied in an experiment at experimental farm "Waiboerhoeve" in Lelystad, the Netherlands. Experimental factors were rumen-degradable protein bal- 


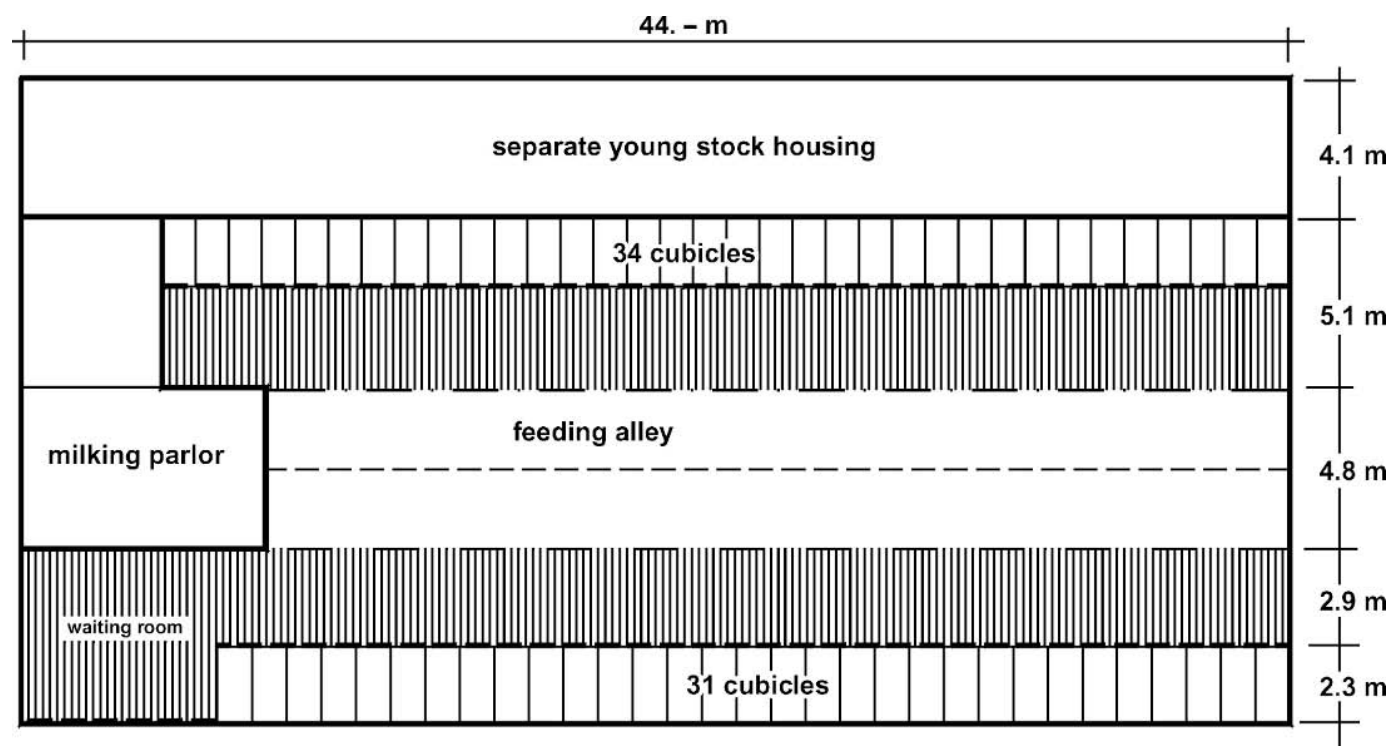

Figure 1. Plan of the naturally ventilated cubicle dairy cow house in Lelystad, the Netherlands.

ance (RDPB) and forage type, both with 3 levels. The usefulness of milk urea content as an indicator of emission reduction was also evaluated.

\section{Experimental Design}

Design and treatments. The experiment had a factorial $3 \times 3$ design with the factors RDPB, calculated according to the Dutch standard OEB (Tamminga et al., 1994), and forage type, expressed as the proportion of corn silage in the forage ration. The RDPB of the diets was set at 3 levels: 0, 500, and $1000 \mathrm{~g} / \mathrm{d}$. Forage types were $100 \%$ grass silage $(\mathbf{G}), 100 \%$ corn silage $(\mathbf{M})$ and $50 \% \mathrm{G}$ and $50 \% \mathrm{M}$ on DM basis (GM). Each diet was administered for 3 -wk periods, with periods randomly distributed over the whole research period. Each diet was repeated at least 3 times. Due to occasional malfunctioning of the emission measurement equipment, some of the treatments had to be repeated more often. The actual sequence of treatments was: GM500, GM1000, G0, M500, M1000, M0, G1000, G500, GM0, GM1000, G0, M500, GM0, GM500, G1000, G500, M0, M1000, GM500, GM0, G500, G0, M1000, GM500, M0, GM1000, GM500, M500, GM0, G1000, G1000, M500, G0, GM1000, M1000, M0. When transitions between subsequent diets were large, the adjustments were made gradually, sometimes taking up to $5 \mathrm{~d}$.

Animals and housing. The Lelystad cubicle house is a naturally ventilated building with 2 rows of 34 and 31 cubicles each, and a central feeding alley. The plan of the house is presented in Figure 1. The slatted floor area is $207 \mathrm{~m}^{2}$. Slurry was stored beneath the slatted floor and the cubicles. The total surface area of the pits is $605 \mathrm{~m}^{2}$. With each new 3 -wk period, the manure level in the pit was reduced to a level of $75 \mathrm{~cm}$ of manure, by mixing the manure, and then removing the surplus manure from the pit. The beginning of every new period was the only time manure was mixed, so the top layer of the manure in the pit was mainly influenced by the diet and not by a buffering effect of the older manure.

During the experiment, 55 to 57 Holstein-Friesian dairy cows were present in the barn, with 8 dry cows present, on average. Dry cows were kept in a separate group from the lactating cows. Ten days before calving, dry cows were housed with milking cows. Therefore, 3 groups of cows were distinguished: milking cows, dry cows fed a different feed than milking cows, and dry cows fed the same feed as milking cows. Young stock was housed in a separate compartment, and did not contribute to the emission from the dairy cow house. The average milk yield of lactating animals was 29.3 $\mathrm{kg} / \mathrm{cow}$ per $\mathrm{d}$ during the experiment.

\section{Measurements and Data}

Feeding and feed sampling. The basal diet consisted of forage (G, M, or GM) and in most cases, a small amount of simple concentrate like soybean meal to balance the $\mathrm{NE}_{\mathrm{L}}$ /protein ratio according to requirements for $\mathrm{NE}_{\mathrm{L}}$ (VEM; Dutch standard based on Van Es, 1975; 1978) and true protein digested in the small intestine (DVE; Dutch standard based on Tamminga et al., 1994). The basal diet was fed ad libitum, using a feed mixer wagon. Supplemental concentrate was fed 
to meet requirements for VEM and DVE with 2 automated concentrate dispensers, registering individual concentrate intake per day. Individual feed intake of the basal diet was registered with a Roughage Intake Control system (Insentec, Marknesse, The Netherlands), consisting of 40 computer-controlled weighing troughs. The individual feed intake was recorded at each meal and used to calculate intake per cow per day. Immediately after feeding the basal diet, random samples of the feed mixture were taken from the weighing troughs for analysis of DM content. The DM content was estimated after drying for $36 \mathrm{~h}$ at $104^{\circ} \mathrm{C}$ in a forced air oven. Weekly, samples of the feedstuffs were taken. The forage samples were stored in a freezer at $-20^{\circ} \mathrm{C}$. Individual forage samples were pooled per 3wk period to create composite samples per period for each batch of forage. Concentrate samples were stored in airtight plastic bags and pooled per batch per period. The forages and concentrates were analyzed for concentrations of DM, CP, crude fiber, crude ash, sugars (except for corn silage), starch (except for grass silage) according to CVB (2002) and the digestibility in vitro (Tilley and Terry, 1963) of the organic matter (except for concentrates) to calculate values for VEM, DVE, and OEB. The required level of RDPB per treatment was adjusted in the basal diet as much as possible. If the required RDPB could be set completely in the basal diet, the additional concentrate had an RDPB of $0 \mathrm{~g} / \mathrm{kg}$. Advantage of this feeding strategy is that the RDPB of the diet of high-yielding cows on high concentrate levels does not differ much from the RDPB of lowyielding cows on low concentrate levels. If the level of $\mathrm{RDPB}$ of the total diet could not be adjusted in the basal diet, the RDPB of the concentrate was adjusted by choice of concentrate ingredients. In addition, with treatment M1000, urea was supplemented to the basal $\operatorname{diet}(1 \%$ of the basal diet as urea on DM basis). In the third and fourth repetition of treatment M500, urea was supplemented to the basal diet in proportions of 0.4 and $0.1 \%$ of the DM, respectively. In general, a weighed amount of a standard mineral and vitamin premix was supplemented to the basal diet. Occasionally, some salt $(\mathrm{NaCl})$ was supplemented to meet $\mathrm{Na}$ requirements according to CVB (2002). The diet of dry cows consisted of $70 \%$ of the forage ration of lactating cows supplemented with $30 \%$ of wheat straw on a DM basis.

Milk urea. Cows were milked twice daily at approximately 0600 and $1700 \mathrm{~h}$. Individual milk yield was recorded each milking. A sample of the bulk milk was taken every 6 milkings and analyzed for milk urea concentration with the Bran \& Luebbe Traacs 800 autoanalyzer by the MCS milk-testing laboratory (Zutphen, the Netherlands) according to de Jong et al. (1992).
Urine composition and volume. On d 1, 3, and 5 of the third week of every 3 -wk period, urine was sampled from each of 15 cows (on average 13 milking cows and 2 dry cows), and pooled. The pooled sample was analyzed for total N, urea, $\mathrm{pH}$, and creatinine. Results were averaged weekly over the $3 \mathrm{~d}$. Urine volume per cow was predicted using a regression model based on the metabolism of K, Na, and N (Bannink et al., 1999). Average urine volume of the herd was computed by statistically weighting the volume for an average milking cow and an average dry cow by their relative proportion in the herd. Predicted urine volume was validated using the creatinine content measured in a pooled urine sample. Urinary creatinine concentration is used frequently as a predictor of urine volume of a cow (Ciszuk and Gebregziabher, 1994; Gonda and Lindberg, 1994; Meijer et al., 1996).

Ammonia emission measurements. Ammonia emission was measured with a concentration ratio method using $\mathrm{SF}_{6}$ (sulfur hexafluoride) as a trace gas injected near the slatted floor. Tracer gas injection points were attached to the separation boards of the cubicles and feeding fences to assure optimal distribution of the gas near the source of $\mathrm{NH}_{3}$ emission. Air at the top of the building was sampled through a system with multiple openings, so a mixed sample was obtained. This sample was analyzed for its concentration of $\mathrm{NH}_{3}$ (by converter and $\mathrm{NOx}$ monitor) and $\mathrm{SF}_{6}$ (by gas chromatograph). The source strength of $\mathrm{NH}_{3}$, being the ammonia emission, was calculated with the following equation, assuming perfect mixing of $\mathrm{NH}_{3}$ and $\mathrm{SF}_{6}$ :

$$
\mathrm{MF}_{\mathrm{SF} 6}: \mathrm{MF}_{\mathrm{NH} 3}=\mathrm{CT}_{\mathrm{SF} 6}: \mathrm{CT}_{\mathrm{NH} 3}
$$

where $\mathrm{MF}_{\mathrm{SF} 6}=$ mass flux of the tracer gas $\mathrm{SF}_{6}$ injected near the floor $(\mathrm{g} / \mathrm{h}) ; \mathrm{MF}_{\mathrm{NH} 3}=$ mass flux of $\mathrm{NH}_{3}$ (from floor and pit; $\mathrm{g} / \mathrm{h}) ; \mathrm{CT}_{\mathrm{SF} 6}=$ concentration of the tracer gas $\mathrm{SF}_{6}$ in the exhaust air $\left(\mathrm{mg} / \mathrm{m}^{3}\right)$; and $\mathrm{CT}_{\mathrm{NH} 3}=$ concentration of $\mathrm{NH}_{3}$ in the exhaust air $\left(\mathrm{mg} / \mathrm{m}^{3}\right)$.

\section{Dynamic Regression Analyses}

Modeling. The effect of diet factors on ammonia emission from the barn was estimated using a dynamic regression model according to Pankratz (1991). In addition, it was determined if the experimental diet factors could be replaced by the factor "bulk milk urea concentration".

To describe the relationship between the observations of response variate $Y$ on day $t$ and the observations of explanatory variate $\mathrm{X}_{1} \ldots \mathrm{X}_{\mathrm{M}}$ on day $t$, day $t-1$ and day $t-2$ the following dynamic regression model was used: 


$$
Y_{t}=C+\sum_{i=1}^{M} \frac{\omega_{i}}{1-\delta_{i} B} X_{i, t}+e_{t}
$$

with $e_{t}$ as the residual contribution on day t. Furthermore, in this equation:

$$
\begin{gathered}
\sum_{i=1}^{M} \frac{\omega_{i}}{1-\delta_{i} B} X_{i, t}= \\
\sum_{i=1}^{M} \omega_{t}\left(X_{i, t}+\delta_{i} X_{i, t-1}+\delta_{i}^{2} X_{i, t-2}+\ldots\right)
\end{gathered}
$$

Within such a dynamic model, regression is performed on the value of the explanatory variates on day $\mathrm{t}$ and previous days $\mathrm{t}-1, \mathrm{t}-2, \ldots$. It is assumed that the weight of the observations on previous days decays with factor $\delta_{\mathrm{i}}$. In case the single observation on day $\mathrm{t}$ is of interest, the decay parameter is 0 , so that $\omega_{i} X_{i}$ gives the effect of $X_{i}$ on that specific day. The use of decay parameters results in efficient models that take into account the observations on previous days. An efficient use of model parameters is important with respect to the accuracy of the predictions. When using models with a surplus of parameters, the contribution of the accuracy of model parameters greatly reduces the accuracy of the response variate. Furthermore, it was assumed that repeated observations of the response variate are correlated and that this correlation can well be described by an $\mathrm{AR}(1)$, autoregressive process of first order. In that case, the following relationship between the residuals on day $t$ and day $t-1$ exists:

$$
e_{t}=a_{t}+\phi e_{t-1}
$$

with $\phi$ as the autocorrelation coefficient and $a_{t}$ as the so-called innovation effect. This $a_{t}$ is assumed to have a normal distribution with average 0 and a variance equal to the innovation variance $\sigma_{a}^{2}$. Furthermore:

$$
\begin{gathered}
e_{t}=a_{t}+\phi a_{t-1}+\phi^{2} a_{t-2}+\ldots \text { or } \\
\text { in a compact formula: } e_{t}=\frac{a_{t}}{1-\phi B}
\end{gathered}
$$

with $B$ as so-called back shift operator: $B a_{t}=a_{t-1}$

By using correllograms of the residues, it was evaluated if there were reasons to doubt the validity of an $\mathrm{AR}(1)$ process for the residues.

Testing and comparing models. The importance of model parameters was evaluated using the common $t$-test $(\mathrm{t}=$ prediction of model parameter/SE). Deviance tests were performed (Genstat 5 Committee, 1993). Differences in $\mathrm{N} * \ln ($ Deviance), with $\mathrm{N}$ as number of repeated observations of the response variate, were used as $\chi^{2}$ variate to test nested models. The criterion "N*ln(Deviance)+2k", with $\mathrm{k}$ being the number of estimated parameters including the missing values that are estimated, was used to choose between 2 models. The model minimizing the criterion was assumed the most adequate. In case there were more models with the same value of $N * \ln ($ Deviance $)+2 \mathrm{k}$, the model with the smallest number of model parameters was chosen. In addition, to compare models, residual variance and the percentage variance accounted for by the model were evaluated. When adjusting the models, estimations of innovation variance $\sigma_{a}^{2}$ and autocorrelation coefficient $\phi$ were made and the total variance $\sigma_{\text {tot }}^{2}=\sigma_{a}^{2} /(1$ $-\phi^{2}$ ) was calculated. Based on the total variance, the percentage variance accounted for was calculated:

$$
\begin{gathered}
r^{2}=100 * \\
\left(1-\frac{\sigma_{\text {candidatemodel }}^{2}}{\sigma_{\text {tot, emptymodel }}^{2}}\right)
\end{gathered}
$$

The empty model for estimating ammonia emission was assumed the model without fixed effects, but with an $\mathrm{AR}(1)$ autoregressive process of order 1 to describe the correlation between the residual contributions. This empty model is written as:

$$
Y_{t}=C_{N H_{3}}+\frac{1}{1-\phi_{N H_{3} B}} a_{t}
$$

where $Y_{t}=\ln$ (emission on day $\mathrm{t}$ ); with emission in kilograms of $\mathrm{NH}_{3}$ per cow per $190 \mathrm{~d}$ (with $190 \mathrm{~d}$ being the average length of an indoor season in the Netherlands); and $\mathrm{t}=1 \ldots 763$.

\section{RESULTS}

\section{Nutrition}

Figure 2 shows the adjusted and the actual RDPB during the experiment with 36 treatments. Transitions between treatments can be clearly seen in most cases by the extreme changes of RDPB level. In most treatments the actual RDPB approached the adjusted level rather well.

Table 1 shows the feed intake, $\mathrm{NE}_{\mathrm{L}}$ intake, ileal digestible protein intake (expressed as DVE according to Tamminga et al., 1994), RDPB (expressed as OEB and calculated according to Tamminga et al., 1994), and intake of $\mathrm{CP}, \mathrm{K}$, and $\mathrm{Na}$ by lactating cows. The intake is averaged for the last week of each treatment period.

Feed intake and intake of $\mathrm{NE}_{\mathrm{L}}, \mathrm{DVE}$, and $\mathrm{CP}$ are correlated positively with the proportion of corn silage in the ration. Average OEB approached the adjusted 


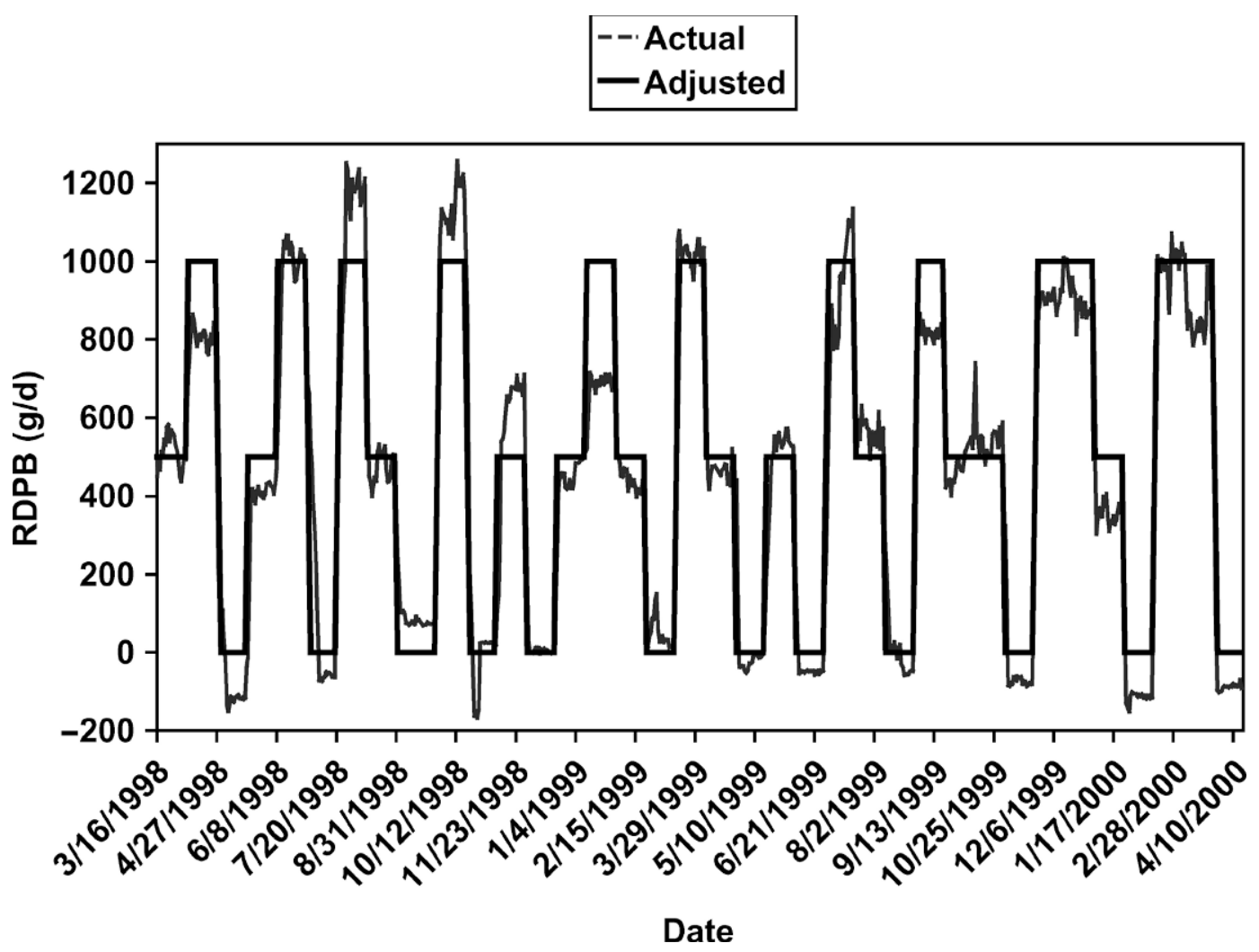

Figure 2. Adjusted and actual rumen-degradable protein balance (RDPB) during the experiment with 36 treatments.

level closely. Crude protein intake was higher with high levels of OEB, but also correlated positively with DM intake. Potassium intake was highest in treatments with high proportions of grass silage, because of the much higher levels of $\mathrm{K}$ in grass silage than in corn silage.

Table 2 shows the percentage of VEM, DVE, K, and $\mathrm{Na}$ requirements accounted for by intake. Values were averaged for the last week of each treatment period of lactating cows. Requirements were according to Dutch standards (CVB, 2002).

The requirements for VEM were not met up to $100 \%$ for grass silage-based treatments. In particular, highyielding cows had negative energy balances, decreasing the average value of the total lactating herd. On the other hand, on corn silage-based rations, low-yielding cows often had positive energy balances, increasing the average VEM intake of the lactating herd to values

Table 1. Feed intake ( $\mathrm{kg}$ of $\mathrm{DM} / \mathrm{cow}$ per $\mathrm{d}), \mathrm{NE}_{\mathrm{L}}$ intake $(\mathrm{kVEM} / \mathrm{cow}$ per $\mathrm{d}$ ) and intake of some nutrients $(\mathrm{g} /$ cow per d) by lactating cows, averaged for the last week of each treatment period.

\begin{tabular}{lcrrrrrrrr}
\hline & \multicolumn{7}{c}{ Treatment $^{1}$} \\
\cline { 2 - 10 } Variable $^{2}$ & G0 & G500 & G1000 & GM0 & GM500 & GM1000 & M0 & M500 & M1000 \\
\hline DM & 19.3 & 19.5 & 19.6 & 21.3 & 21.5 & 21.8 & 21.8 & 22.1 & 22.2 \\
kVEM & 17.8 & 17.7 & 18.2 & 19.9 & 20.2 & 20.5 & 21.2 & 21.6 & 21.2 \\
DVE & 1616 & 1620 & 1638 & 1819 & 1824 & 1845 & 1975 & 2021 & 2003 \\
OEB & -66 & 484 & 906 & -8 & 503 & 948 & -42 & 505 & 996 \\
Crude protein & 2716 & 3131 & 3513 & 3031 & 3549 & 3978 & 3137 & 3740 & 4197 \\
K & 477 & 528 & 578 & 461 & 459 & 477 & 303 & 302 & 295 \\
Na & 38 & 46 & 43 & 46 & 46 & 51 & 39 & 39 & 38 \\
\hline
\end{tabular}

${ }^{1}$ Treatments comprised $100 \%$ grass silage $(\mathrm{G}), 50 \%$ grass silage and $50 \%$ corn silage $(\mathrm{GM})$, and $100 \%$ corn silage $(\mathrm{M})$, at 3 levels of rumen-degradable protein balance each $(0,500$, and $1000 \mathrm{~g} / \mathrm{d})$.

${ }^{2} \mathrm{kVEM}=\mathrm{NE}_{\mathrm{L}}$ according to Dutch standards, $\times 1000 ; \mathrm{DVE}=$ true protein digested in the small intestine according to Dutch standards; OEB = rumen-degradable protein balance according to Dutch standards. 
Table 2. Percentage of VEM, DVE, K, and Na requirements accounted for by intake averaged for the last week of each treatment period for lactating cows. ${ }^{1}$

\begin{tabular}{lrrrrrrrrr}
\hline & \multicolumn{7}{c}{ Treatment $^{2}$} \\
\cline { 2 - 10 } Variable & G0 & G500 & G1000 & GM0 & GM500 & GM1000 & M0 & M500 & M1000 \\
\hline VEM & 93 & 91 & 94 & 98 & 99 & 98 & 103 & 107 & 103 \\
DVE & 104 & 104 & 101 & 104 & 101 & 98 & 100 & 103 & 102 \\
K & 656 & 708 & 780 & 602 & 585 & 595 & 377 & 388 & 363 \\
Na & 186 & 221 & 204 & 214 & 210 & 228 & 174 & 179 & 169 \\
\hline
\end{tabular}

${ }^{1} \mathrm{VEM}=\mathrm{NE}_{\mathrm{L}}$ according to Dutch standards; DVE = true protein digested in the small intestine according to Dutch standards.

${ }^{2}$ Treatments comprised $100 \%$ grass silage (G), $50 \%$ grass silage and $50 \%$ corn silage (GM), and $100 \%$ corn silage (M), at 3 levels of rumen-degradable protein balance each $(0,500$, and $1000 \mathrm{~g} / \mathrm{d})$.

above $100 \%$ of requirements. The intake of ileal digestible protein (DVE) was close to requirements, with values near $100 \%$ (Table 2). Intake of $\mathrm{Na}$ and $\mathrm{K}$ was higher than the required level, but not different from levels in common practice.

\section{Milk Urea}

Figure 3 shows the development of the urea concentration in bulk milk during the course of the experiment. Levels varied between 10 and $59 \mathrm{mg} / 100 \mathrm{~g}$ of milk. Transitions between treatments can well be recognized in most cases by the extreme changes of milk urea levels.

\section{Urine}

Predicted urine volume varied for various $\operatorname{diets}(P<$ 0.05). On average, urine volume was highest for diets containing grass silage $(35.1 \mathrm{~kg} / \mathrm{d})$ and lowest for diets containing corn silage $(21.9 \mathrm{~kg} / \mathrm{d})$. Urinary $\mathrm{N}$ excretion increased as OEB level of the diet increased $(P<0.01)$.

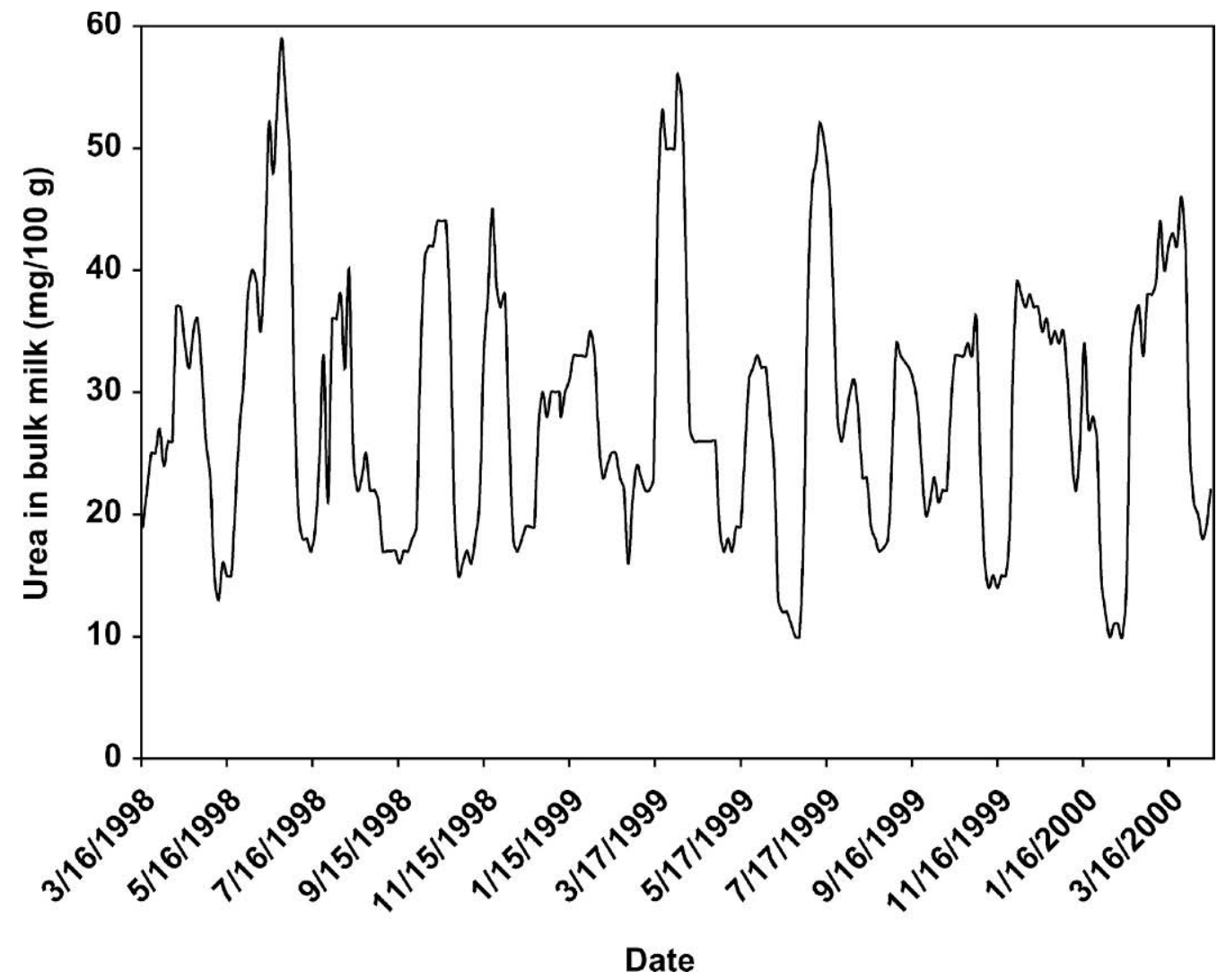

Figure 3. Urea concentration in bulk milk (mg/100 g) during the course of the experiment. 


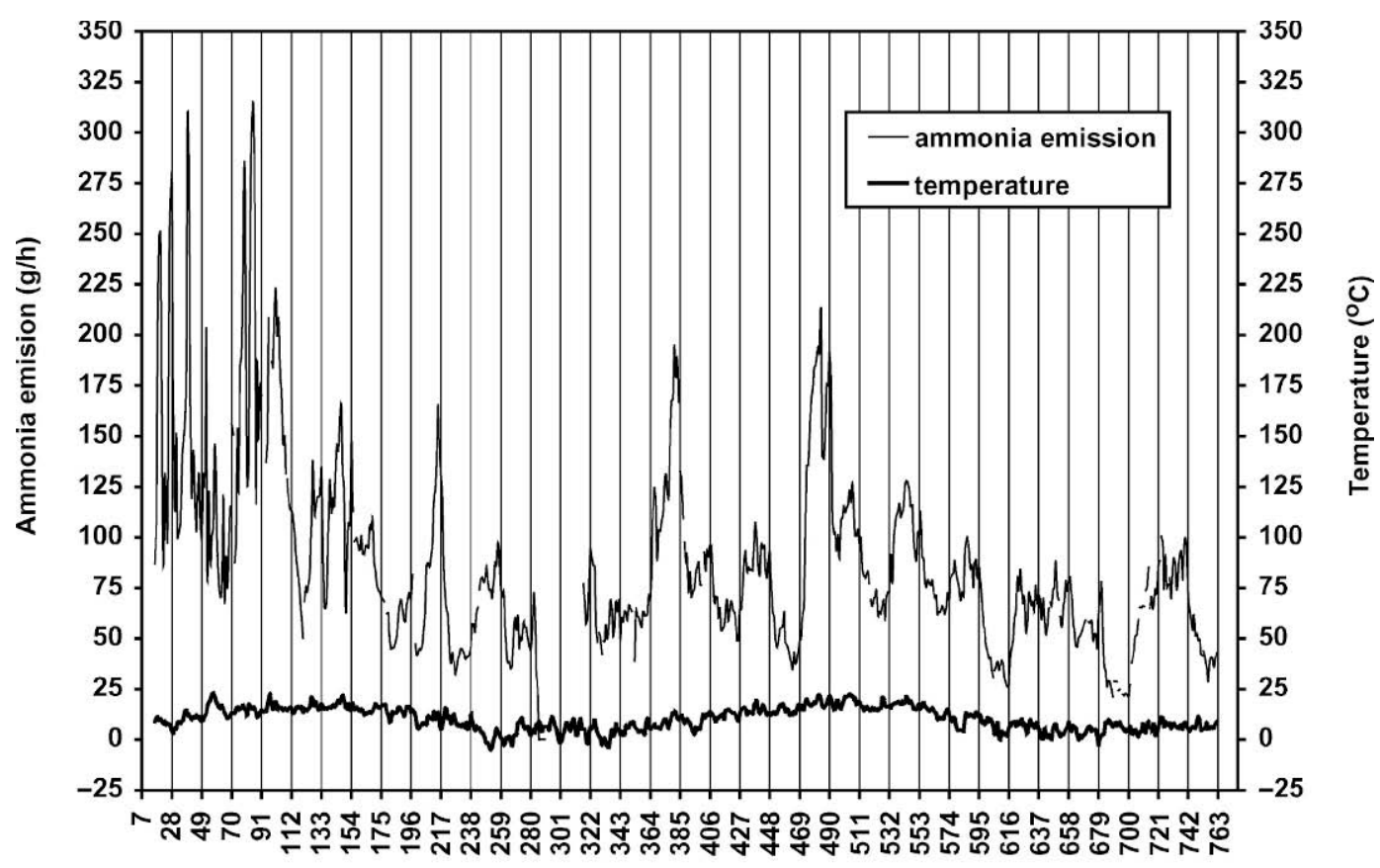

Experimental day

Figure 4. Course of daily averaged ammonia emission $(\mathrm{g} / \mathrm{h})$ and outdoor temperature $\left({ }^{\circ} \mathrm{C}\right)$ during the experiment.

In addition, urinary $\mathrm{N}$ excretion was slightly higher for cows fed corn than for cows fed grass silage $(P<0.01)$. Results on urine composition and urine volume are described in more detail by de Boer et al. (2002) and Monteny et al. (2002).

\section{Ammonia Emission}

Figure 4 shows the course of daily averaged $\mathrm{NH}_{3}$ emission $(\mathrm{g} / \mathrm{h})$ and daily averaged outdoor temperature $\left({ }^{\circ} \mathrm{C}\right)$. During the first 5 periods, the measurement equipment malfunctioned occasionally, resulting in high fluctuations in emission data. In period 6 , the $\mathrm{NH}_{3}$ measurement equipment was replaced and the first 5 treatments were repeated once each in random order. Afterwards equipment functioned well most of the time. Due to occasional power outages missing emission values occurred. In that case, treatments were repeated an extra time. Missing values were interpolated when possible, using a combination of time series analysis and regression.

The observed $\mathrm{NH}_{3}$ emission was correlated with temperature. The first impression was a jagged course of the emission, which was caused by fluctuating weather conditions and changing treatments during the experiment. On examining the emission data closely, it appears that experimental treatments affect the emission. Emission and RDPB (OEB) seem to be positively corre- lated. To quantify the relationship between experimental factors and $\mathrm{NH}_{3}$ emission, a statistical analysis is necessary. By means of a time series analysis (dynamic regression model), it was possible to correct for disturbing influences such as weather conditions. Dynamic regression models for $\mathrm{NH}_{3}$ emission from the barn were derived based on (1) feed characteristics and temperature, and (2) urea content in bulk milk and temperature.

\section{Emission Models}

Data description. The emission data set consisted of $763 \mathrm{~d}$. Emission values are $Y_{t}\left(\mathrm{~g}\right.$ of $\left.\mathrm{NH}_{3} / \mathrm{d}\right)$ with $\mathrm{t}=$ 1 to 763 . Analysis was performed on the logarithm of the emission measurements ( $\mathrm{Ln} \mathrm{kg}$ of $\mathrm{NH}_{3} /$ cow per 190 d). Day 1 was March 16, 1998; d 763 was April 16, 2000. Emission measurements started on d 17 (April 1, 1998). The shelter with $\mathrm{NH}_{3}$ emission equipment was replaced on $\mathrm{d} 94$. Until that time, level and variance of the values appeared to be deviant. Variance based on the first shelter appeared to be 9 times higher than variance base on the second shelter. Therefore, emission values of $d 1$ to 94 were weighed with factor 0.111 .*

\footnotetext{
*Additional arguments to involve the data of the first shelter in the final analysis were collected by means of a dynamic regression analysis with only the data of d 95 to 763 . Parameter estimates of this additional model were quite similar to those of the original model, however standard errors of the additional model were higher. Information regarding the additional model, based on the limited dataset, is not given in this paper, because of the abundance of information.
} 
The covariates temperature, wind direction, wind speed, and day of the week were measured daily. Temperature and wind speed were added to the model as: $T_{t}=$ temperature -15 and $W s_{t}=$ Wind speed -4.1 . This means that models were standardized for a temperature of $15^{\circ} \mathrm{C}$ and a wind speed of $4.1 \mathrm{~m} / \mathrm{s}$.

Model using RDPB and forage type. An emission model was derived stepwise, starting with an empty model (equation 4). An overview of the results of the stepwise modeling is given in Table 3 . In this table the empty model is numbered A1. The full model was derived 2 steps. First by implementing the variates for shelter $\left(S_{t}\right)$, temperature $\left(T_{t}\right.$, linear and squared), wind direction (cyclometrical function $\left.W r_{t}\right)$, wind speed $\left(W s_{t}\right.$, linear and squared) and day of the week (cyclometrical function $D_{t}$ ). This resulted in model number A2. Next, the parameters OEB $\left(O_{t}\right.$, linear and squared) and corn proportion $\left(M_{t}\right.$, linear and squared) were added, resulting in full model number A3:

$$
\begin{gathered}
Y_{t}=C+\omega_{1} S_{t}+\omega_{21} T_{t}+\omega_{22} T_{t}^{2}+\omega_{31} \cos \left(\frac{2 \pi W r_{t}}{360^{\circ}}\right) \\
+\omega_{32} \sin \left(\frac{2 \pi W r_{t}}{360^{\circ}}\right)+\omega_{33} \cos \left(\frac{2 \pi W r_{t}}{180^{\circ}}\right)+\omega_{34} \sin \left(\frac{2 \pi W r_{t}}{180^{\circ}}\right) \\
+\omega_{41} W \mathrm{~s}_{t}+\omega_{42} W \mathrm{~s}_{t}^{2}+\omega_{51} \cos \left(\frac{2 \pi D_{t}}{7}\right) \\
+\omega_{52} \sin \left(\frac{2 \pi D_{t}}{7}\right)+\frac{\omega_{61}}{1-\delta_{6} B} M_{t}+\frac{\omega_{62}}{1-\delta_{6} B} M_{t}^{2} \\
+\frac{\omega_{71}}{1-\delta_{7} B} O_{t}+\frac{\omega_{72}}{1-\delta_{7} B} O_{t}^{2}+\frac{\omega_{8}}{1-\delta_{8} B} O_{t} M_{t} \\
+\frac{1}{1-\phi B} a_{t}
\end{gathered}
$$

where $t$ day $(0 \ldots 763) ; Y_{t}$ natural logarithm of the $\mathrm{NH}_{3}$ emission ( $\mathrm{kg} \mathrm{NH} /$ /cow per $190 \mathrm{~d}$ ) on day t; $C$ constant; $S_{t}$ index for shelter on day t $(1=$ first shelter, $0=$ second shelter); $T_{t}$ (temperature -15$)$ on day $\mathrm{t}\left({ }^{\circ} \mathrm{C}\right) ; W r_{t}$ wind direction on day $\mathrm{t}\left({ }^{\circ} \mathrm{C}\right) ; W s_{t}$ (wind speed -4.1 ) on day $\mathrm{t}$ $(\mathrm{m} / \mathrm{s}) ; D_{t}$ day of the week on day $\mathrm{t}(1=$ Monday, $2=$ Tuesday, $\ldots, 7=$ Sunday); $O_{t}=$ OEB on day t $(\mathrm{kg} / \mathrm{cow}$ per d); $M_{t}$ corn silage proportion on day t [= corn silage DM intake/ (corn silage DM + grass silage DM intake)]; $\phi$ autocorrelation coefficient; $a_{t} \sim N\left(0, \sigma_{a}^{2}\right)$ innovation effect with innovation variance $\sigma_{a}^{2}, B$ back shift operator, $B X_{t}=X_{t-1}, \omega$ parameters for the size of effects; and $\delta$ parameters for decay effects.

Adding the variates for climate, shelter, and day of the week gave a reduction of the criterion of 111.2 with 11 degrees of freedom, $P\left(\chi_{11 \text { d.f. }}^{2}>111.2\right)<0.001$. The criterion was reduced even more (142.2 with 8 degrees of freedom) by adding $O_{t}$ (linear and squared) and $M_{t}$ (linear and squared), $P\left(\chi_{88 \text { d.f. }}^{2}>142.2\right)<0.001$. In both cases, effects were significant; however, a $t$-test showed not all parameters had a significant contribution. Therefore, the model was simplified by removing nonsignificant parameters: $O_{t} \times M_{t}$ (resulting in A4), $M_{t}^{2}$ (resulting in A5), $W \mathrm{~s}_{t}^{2}$ (resulting in A6), and $T_{t}^{2}$ (resulting in A7). Furthermore, decay parameters for OEB and corn proportion were assumed equal (resulting in A8), and the nonsignificant parameter $D_{t}$ was eliminated (resulting in A9). Eliminating the effect of wind direction (resulting in A10) and linear effect of wind speed (resulting in A11) showed that these parameters had a significant contribution to the model. However, the simplified model A11 (without these parameter) shows only minor differences compared with model A9 (with regard to total residual variance and variance accounted for). Therefore, model A11 was chosen as the final model:

$$
\begin{gathered}
Z_{t}=C+\omega_{1} S_{t}+\omega_{2} T_{t}+\frac{\omega_{6}}{1-\delta B} M_{t} \\
+\frac{\omega_{71}}{1-\delta B} O_{t}+\frac{\omega_{72}}{1-\delta B} O_{t}^{2}+\frac{1}{1-\phi B} a_{t}
\end{gathered}
$$

Eliminating nonsignificant parameters resulted in a reduction of the criterion with 28.9 with 13 degrees of freedom compared with the full model A3, $P\left(\chi_{13 d . f .}^{2}>\right.$ $28.9=0.007$. This means that the final model A11 differed significantly from full model A3. Note that estimates for variances, $\phi$ and the variance accounted for also correspond. Further residual analysis showed that model A11 fitted well and that there was no deviation from normality. An evaluation of correllograms showed that the dynamic regression model gives satisfactory results. Because of the abundant information, this model control is not described in detail in this paper.

When parameter estimates were included, model A11 was as follows:

$$
\begin{aligned}
& Y_{t}=1.3199+0.518 S_{t}+0.02716 T_{t} \\
& +\frac{0.0956}{1-0.7452 B} M_{t}+\frac{0.3353}{1-0.7452 B} O_{t} \\
& -\frac{0.1256}{1-0.7452 B} O_{t}^{2}+\frac{1}{1-0.8405 B} a_{t}
\end{aligned}
$$

Predictions of $\mathrm{NH}_{3}$ emission from the barn were made with equation 6 for several values for temperature, OEB, and proportion of corn silage. Results are shown in Table 4.

Temperature appears to have a positive correlation with $\mathrm{NH}_{3}$ emission. In general, $\mathrm{NH}_{3}$ emission from the 
Table 3. Results of dynamic regression analysis: Model characteristics.

\begin{tabular}{|c|c|c|c|c|c|c|c|c|c|c|c|c|c|c|}
\hline \multirow{2}{*}{\multicolumn{2}{|c|}{$\begin{array}{l}\text { Model } \\
\text { and } \\
\text { description }^{2}\end{array}$}} & \multicolumn{13}{|c|}{ Model characteristics ${ }^{1}$} \\
\hline & & \multirow{2}{*}{$\frac{\mathrm{dev}}{10.99}$} & \multirow{2}{*}{$\frac{\mathrm{s}^{2} \mathrm{a}}{0.01738}$} & \multirow{2}{*}{$\frac{\mathrm{df}}{630}$} & \multirow{2}{*}{$\begin{array}{l}\text { phi } \\
0.9557\end{array}$} & \multirow{2}{*}{$\frac{\mathrm{N}}{763}$} & \multirow{2}{*}{$\frac{\mathrm{k}}{133}$} & \multirow{2}{*}{$\begin{array}{l}\mathrm{Nln}(\mathrm{D}) \\
1828.9\end{array}$} & \multirow{2}{*}{$\begin{array}{l}\mathrm{N} \ln (\mathrm{D})+2 \mathrm{k} \\
2094.9\end{array}$} & \multirow{2}{*}{$\frac{\mathrm{s}^{2} \text { tot }}{0.2006}$} & \multirow{2}{*}{$\frac{r^{2}}{0.00}$} & \multirow{2}{*}{$\frac{\mathrm{ddf}}{0}$} & \multirow{2}{*}{$\frac{\text { dcrit }}{0}$} & \multirow{2}{*}{$\begin{array}{l}\text { Remarks on } \\
\text { ddf and dcrit }\end{array}$} \\
\hline A1 & Empty model & & & & & & & & & & & & & \\
\hline $\mathrm{A} 2$ & + Climate & 9.230 & 0.01487 & 619 & 0.9481 & 763 & 144 & 1695.7 & 1983.7 & 0.1471 & 26.69 & 11 & -111.2 & compared with A1 \\
\hline A3 & Full model & 7.501 & 0.01226 & 611 & 0.8314 & 763 & 152 & 1537.5 & 1841.5 & 0.0397 & 80.21 & 19 & -253.4 & compared with A1 \\
\hline $\mathrm{A} 4$ & $-\mathrm{O} * \mathrm{M}$ & 7.500 & 0.01222 & 613 & 0.8343 & 763 & 150 & 1537.4 & 1837.4 & 0.0402 & 79.96 & -2 & -4.1 & compared with A3 \\
\hline A5 & $-\mathrm{M}^{2}$ & 7.501 & 0.01220 & 614 & 0.8362 & 763 & 149 & 1537.5 & 1835.5 & 0.0406 & 79.78 & -3 & -6.0 & compared with A3 \\
\hline A6 & $-W s^{2}$ & 7.505 & 0.01218 & 615 & 0.8349 & 763 & 148 & 1537.9 & 1833.9 & 0.0402 & 79.96 & -4 & -7.6 & compared with A3 \\
\hline A7 & $-\mathrm{T}^{2}$ & 7.531 & 0.01221 & 616 & 0.8388 & 763 & 147 & 1540.5 & 1834.5 & 0.0412 & 79.47 & -5 & -7.0 & compared with A3 \\
\hline A8 & $\mathrm{d} 1=\mathrm{d} 2$ & 7.531 & 0.01219 & 617 & 0.8384 & 763 & 146 & 1540.5 & 1832.5 & 0.0410 & 79.55 & -6 & -9.0 & compared with A3 \\
\hline A9 & $-\mathrm{D}$ & 7.594 & 0.01225 & 619 & 0.8367 & 763 & 144 & 1546.9 & 1834.9 & 0.0408 & 79.64 & -8 & -6.6 & compared with A3 \\
\hline A10 & $-\mathrm{Wr}$ & 7.901 & 0.01266 & 623 & 0.8320 & 763 & 140 & 1577.1 & 1857.1 & 0.0411 & 79.50 & -12 & 15.6 & compared with A3 \\
\hline A11 & $-\mathrm{Ws}$ & 8.061 & 0.01290 & 624 & 0.8405 & 763 & 139 & 1592.4 & 1870.4 & 0.0439 & 78.09 & -13 & 28.9 & compared with A3 \\
\hline $\mathrm{C} 1$ & + DVE, $\mathrm{DVE}^{2}$ & 8.035 & 0.01292 & 621 & 0.8406 & 763 & 142 & 1589.9 & 1873.9 & 0.0440 & 78.05 & 3 & 3.5 & compared with A11 \\
\hline $\mathrm{C} 2$ & $-\mathrm{M}$ & 8.168 & 0.01311 & 622 & 0.8556 & 763 & 141 & 1602.5 & 1884.5 & 0.0489 & 75.61 & -1 & 10.6 & compared with C1 \\
\hline C3 & $\mathrm{d} 6=\mathrm{d} 7$ & 8.168 & 0.01309 & 623 & 0.8563 & 763 & 140 & 1602.5 & 1882.5 & 0.0491 & 75.54 & -2 & 8.6 & compared with $\mathrm{C} 1$ \\
\hline $\mathrm{C} 4$ & + OEB*DVE & 8.164 & 0.01310 & 622 & 0.8579 & 763 & 141 & 1602.1 & 1884.1 & 0.0496 & 75.27 & -1 & 10.2 & compared with $\mathrm{C} 1$ \\
\hline C5 & - OEB*DVE, DVE ${ }^{2}$ & 8.169 & 0.01307 & 624 & 0.8562 & 763 & 139 & 1602.6 & 1880.6 & 0.0490 & 75.59 & -3 & 6.7 & compared with $\mathrm{C} 1$ \\
\hline D1 & $+\mathrm{K}$ & 8.060 & 0.01294 & 622 & 0.8384 & 763 & 141 & 1592.3 & 1874.3 & 0.0436 & 78.29 & 1 & 0.4 & compared with $\mathrm{C} 1$ \\
\hline D2 & $+\mathrm{Na}$ & 8.087 & 0.01298 & 622 & 0.8405 & 763 & 141 & 1594.9 & 1876.9 & 0.0442 & 77.96 & 2 & 3.0 & compared with $\mathrm{C} 1$ \\
\hline B1 & $+\mathrm{U}, \mathrm{U}^{2}$ & 7.994 & 0.01285 & 621 & 0.8298 & 763 & 142 & 1586.0 & 1870.0 & 0.0413 & 79.43 & 2 & -0.4 & compared with A11 \\
\hline B2 & $-\mathrm{OEB}^{2}$ & 8.043 & 0.01291 & 622 & 0.8454 & 763 & 141 & 1590.7 & 1872.7 & 0.0453 & 77.44 & -1 & 2.7 & compared with B1 \\
\hline B3 & - OEB & 8.393 & 0.01345 & 623 & 0.8446 & 763 & 140 & 1623.2 & 1903.2 & 0.0469 & 76.61 & -2 & 33.2 & compared with B1 \\
\hline B4 & $-\mathrm{M}$ & 8.428 & 0.01346 & 625 & 0.8504 & 763 & 138 & 1626.4 & 1902.4 & 0.0486 & 75.76 & -4 & 32.4 & compared with B1 \\
\hline
\end{tabular}

${ }^{1} \mathrm{dev}=$ Deviance; $\mathrm{s}^{2} \mathrm{a}=$ innovation variance; $\mathrm{df}=$ degrees of freedom; phi = autocorrelation coefficient; $\mathrm{N}=$ number of observations; $\mathrm{k}=$ number of estimated parameters (= number of estimates + missing values which are estimated); $\mathrm{N} \ln (\mathrm{D})+2 \mathrm{k}=\mathrm{N} * \ln ($ deviance $)+2 \mathrm{k}$ : criterion for deviance test; $\mathrm{Nln}(\mathrm{D})=\mathrm{N} * \ln \left(\right.$ deviance); $\mathrm{s}^{2}$ tot $=$ total variance; $\mathrm{r}^{2}=$ percentage variance accounted for; ddf = delta degrees of freedom (reduction of df compared with an earlier model of the stepwise analysis); dcrit = delta criterion (increase of the criterion compared with an earlier model of the stepwise analysis).

${ }^{2} \mathrm{M}=$ Corn proportion; $\mathrm{O}=\mathrm{OEB}=$ rumen-degradable protein according to Dutch standard; $\mathrm{WS}=$ wind speed; $\mathrm{T}=$ temperature $-15 ; \mathrm{Wr}=$ wind direction; $\mathrm{d}=$ decay parameter;

$\mathrm{D}=$ day of the week; $\mathrm{u}=$ bulk milk urea concentration; $\mathrm{K}$ = potassium; Na = sodium; DVE = true protein digested in the small intestine according to Dutch standards. 
Table 4. Ammonia emission from the dairy barn ( $\mathrm{kg}$ of $\mathrm{NH}_{3} / \mathrm{cow}$ per $190 \mathrm{~d}$ ) with different temperature $\left({ }^{\circ} \mathrm{C}\right)$, OEB (g/lactating cow per d) and corn silage proportion (estimated with equation 6 ).

\begin{tabular}{lcccc}
\hline & \multicolumn{3}{c}{ Proportion of corn silage in forage DM, \% } \\
\cline { 2 - 5 } Temperature, ${ }^{\circ} \mathrm{C}$ & $\mathrm{OEB},{ }^{1}$ & 0 & 50 & 100 \\
\hline 10 & 0 & 3.27 & 3.94 & 4.76 \\
10 & 500 & 5.58 & 6.73 & 8.12 \\
10 & 1000 & 7.44 & 8.98 & 5.45 \\
15 & 0 & 3.74 & 7.52 & 9.30 \\
15 & 500 & 6.39 & 1.71 & 12.41 \\
15 & 1000 & 8.52 & 10.28 & \\
\hline
\end{tabular}

${ }^{1} \mathrm{OEB}=$ Rumen-degradable protein balance according to Dutch standards.

barn increases $2.7 \%$ when outdoor temperature increased by $1.0^{\circ} \mathrm{C}$. Furthermore, OEB is correlated positively with emission. Figure 5 shows the relationship between $\mathrm{OEB}$ and $\mathrm{NH}_{3}$ emission for the GM rations (forage DM intake $=50 \%$ grass silage $+50 \%$ corn silage). Temperature was standardized to $15^{\circ} \mathrm{C}$. In addition, Figure 5 shows the $95 \%$ confidence interval based on estimating accuracy of the parameters.

Corn silage proportion appeared to be correlated positively with $\mathrm{NH}_{3}$ emission. However, it is assumed that this is not a causal relationship. This is evaluated in more detail and described in the discussion.

Model based on milk urea and temperature. Model A11 was adjusted stepwise into a model for estimating $\mathrm{NH}_{3}$ emission using the bulk milk urea concentration. An overview of this analysis is given in Table
3. First, the bulk milk urea concentration $\left(U_{t}\right.$, linear and squared) was added (resulting in model number B1). The criterion appeared to decrease, which means that model B1 is better than A11. Next, parameters $O_{t}$ (linear and squared) and $M_{t}$ were eliminated (resulting in B2, B3, and B4, respectively). The equation of model $\mathrm{B} 4$ is:

$$
\begin{aligned}
Y_{t}= & C+\omega_{1} S_{t}+\omega_{2} T_{t}+\frac{\omega_{31}}{1-\delta B} U_{t} \\
& +\frac{\omega_{32}}{1-\delta B} U_{t}^{2}+\frac{1}{1-\phi B} a_{t}
\end{aligned}
$$

where $U_{t}$ bulk milk urea concentration on day $\mathrm{t}(\mathrm{mg} /$ $100 \mathrm{~g})$.

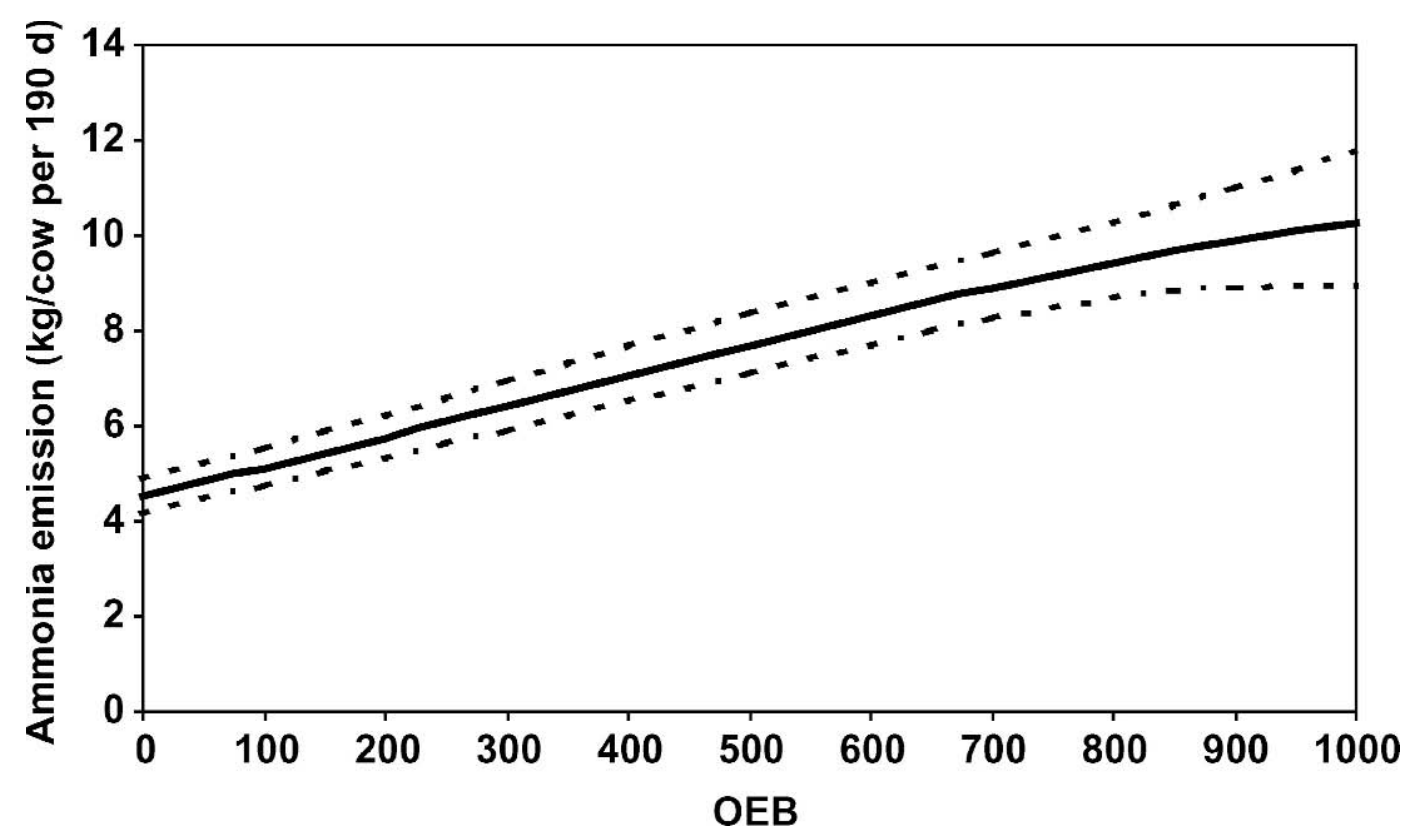

Figure 5. Effect of rumen-degradable protein balance according to Dutch standards (OEB; g/cow per d) on $\mathrm{NH}_{3}$ emission from the Lelystad dairy house ( $\mathrm{kg}$ of $\mathrm{NH}_{3} / \mathrm{cow}$ per $190 \mathrm{~d}$ ) with forage type GM (50\% grass silage and 50\% corn silage). Lower and upper limits (- - -) of 95\% confidence interval based on estimating accuracy of the parameters. 


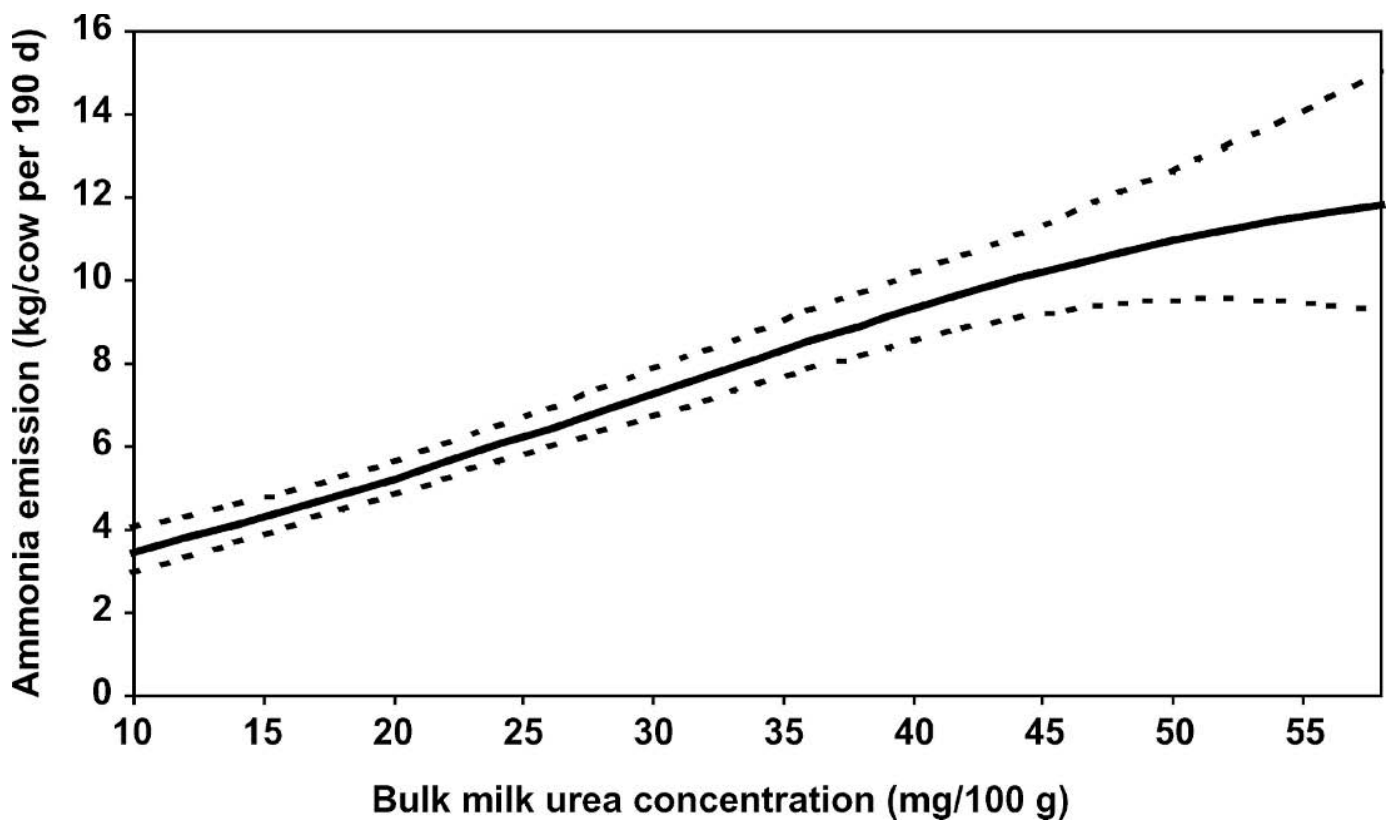

Figure 6. Ammonia emission ( $\mathrm{kg}$ of $\mathrm{NH}_{3} / \mathrm{cow}$ per $190 \mathrm{~d}$ ) vs. bulk milk urea concentration (mg/100 g) at the Lelystad dairy house. Lower and upper limits (- - ) of $95 \%$ confidence interval based on estimating accuracy of the parameters.

Compared with model B1, the criterion of B4 is higher (32.4 units) with a decrease of 4 degrees of freedom, $P\left(\chi_{4 d . f .}^{2}>32.4\right)<0.001$. Furthermore, variances of model B4 are somewhat higher and $r^{2}$ is somewhat lower. From a statistical point of view, model B4 was less suitable than B1. However, taking into account the practical relevance of the model, $\mathrm{B} 4$ can be used as well, or even better than $\mathrm{B} 1$. In model $\mathrm{B} 1$, with $U_{t}, O_{t}$, and $M_{t}$ as explanatory parameters, $t$-test showed that all parameters had a significant contribution to the model. However, parameter estimations appeared to be remarkably low, because effects were divided over parameters that are confounded. Because $U_{t}, O_{t}$, and $M_{t}$ are interrelated, effects in model B1 are underestimated. Furthermore, the use of the model with confounded parameters is dangerous because the milk urea concentration will not vary much at fixed levels for OEB and corn silage proportion.

When parameter estimations were included, model B4 was as follows:

$$
\begin{gathered}
Y_{t}=0.751+0.491 S_{t}+0.0276 T_{t}+\frac{0.01905}{1-0.6437 B} U_{t} \\
-\frac{0.0001466}{1-0.6437 B} U_{t}^{2}+\frac{1}{1-0.8504 B}{ }^{a_{t}}
\end{gathered}
$$

Figure 6 shows the relationship between bulk milk urea concentration and $\mathrm{NH}_{3}$ emission from the dairy barn, based on equation 7 . Temperature was standard- ized at $15^{\circ} \mathrm{C}$. In addition, Figure 6 shows the $95 \%$ confidence interval based on estimating accuracy of the parameters.

Bulk milk urea concentration and temperature were correlated positively with $\mathrm{NH}_{3}$ emission $\left(\mathrm{r}^{2}=76 \%\right.$; model B4). The model shows that a reduction in urea concentration from 40 to $20 \mathrm{mg} / 100 \mathrm{~g}$ of milk corresponds with an emission reduction of $44 \%$ from the Lelystad dairy barn.

\section{DISCUSSION}

This study showed that $\mathrm{NH}_{3}$ emission from dairy barns could be estimated using RDPB and forage type as explanatory variates. It is assumed that the forage type itself does not cause an effect on $\mathrm{NH}_{3}$ emission. Probably, chemical or nutrient composition of the forage is the causal factor.

In the experiment, forage type could be interrelated with other factors that might have an effect on $\mathrm{NH}_{3}$ emission. The factors ileal digestible protein (DVE), potassium, and sodium were evaluated.

\section{DVE Intake}

Table 1 showed that DVE intake of lactating cows was higher with higher corn silage proportions. Average daily DVE intake was 200 and $400 \mathrm{~g} / \mathrm{cow}$ higher on GM and $\mathrm{M}$, respectively, than on $\mathrm{G}$. This increased intake was not caused by feeding above DVE requirements 
(Table 2). Moreover, the higher DVE intake is caused by higher DM intake on GM and M than on G. The increased DVE intake on corn silage-based rations was mainly used for milk protein production, possibly in combination with protein retention in body reserves. However, the use of DVE for milk (protein) synthesis had an efficiency of only 64\% (Tamminga et al., 1994). Therefore, 36\% will contribute to urinary $\mathrm{N}$ losses (urea). These higher urinary urea losses were reflected in a higher milk urea content and a higher ammonia emission.

It was evaluated if, in model A11, parameter $M_{t}$ could be replaced by DVE intake. Results of the stepwise analysis were given in Table 3. First, DVE intake $\left(D V E_{t}\right.$, linear and squared) was added to model A11 (resulting in model number C1). This did not significantly decrease the criterion. Next, eliminating $M_{t}$, caused a significant increase of the criterion, $P\left(\chi_{1}^{2}\right.$ d.f. $>$ $10.6)<0.001$ (model $\mathrm{C} 2$ ). In addition, it was evaluated if decay parameters were equal (resulting in model C3) and if there was interaction between OEB and DVE intake (resulting in model C4). This interaction did not appear significant; neither did the squared effect of DVE intake. The final model C5 did not differ significantly from model $\mathrm{C} 1, P\left(\chi_{3 \text { d.f. }}^{2}>6.7\right)=0.08$. The total variance and the variance accounted for did not differ between the models. Including the parameter estimations, model C5 is written as:

$$
\begin{gathered}
Y_{t}=0.504+0.457 S_{t}+0.02738 T_{t} \\
+\frac{0.1558}{1-0.7536 B} D V E_{t}+\frac{0.3152}{1-0.7536 B} O_{t} \\
-\frac{0.1169}{1-0.7536 B} O_{t}^{2}+\frac{1}{1-0.8562 B} a_{t}
\end{gathered}
$$

where $D V E_{t}=\mathrm{DVE}$ intake on day $\mathrm{t}(\mathrm{kg} / \mathrm{cow}$ per d).

Model C5 was based on OEB and DVE intake and no longer on corn silage proportion. However, it should be noted that DVE intake and corn silage proportion were interrelated. Therefore, on statistical grounds, we were unable to demonstrate unambiguously that DVE intake itself is a good explanatory variable. However, a causal relationship between DVE intake and $\mathrm{NH}_{3}$ emission was demonstrated on physiological grounds.

\section{Potassium and Sodium}

Based on the analogous analysis for DVE intake, we determined if adding potassium and sodium to the model would significantly improve the model. This resulted in models D1 and D2 respectively (Table 3). Neither parameter improved the model.

\section{Practical Relevance}

There are good prospects for reducing $\mathrm{NH}_{3}$ emission from dairy barns by influencing cows' diet. Emissionreducing measures should aim to reduce surplus protein in the ration; they should not aim to reduce the urine volume. An RDPB near $0 \mathrm{~g} / \mathrm{d}$, together with feeding according to requirements for $\mathrm{NE}_{\mathrm{L}}$ and ileal digestible protein, results in low volatilization of $\mathrm{NH}_{3}$. Bulk milk urea concentration is a useful indicator of emission reduction on dairy farms. In naturally ventilated dairy barns, a reduction of the bulk milk urea concentration of $1 \mathrm{mg} / 100 \mathrm{~g}$ of milk is expected to reduce $\mathrm{NH}_{3}$ emission from the barn by approximately $2.5 \%$. In the Netherlands, the national average milk urea content decreased from 30 to $25 \mathrm{mg} / 100 \mathrm{~g}$ of milk from 1998 to 2001, indicating that Dutch dairy farmers were able to substantially reduce $\mathrm{NH}_{3}$ emission by taking feeding measures (van Duinkerken et al., 2003).

\section{CONCLUSIONS}

The emission of $\mathrm{NH}_{3}$ from naturally ventilated dairy cow barns was strongly influenced by diet. Emissions were reduced by decreasing the rumen-degradable protein balance of the ration. Reduction of $\mathrm{NH}_{3}$ emission can be predicted accurately by a model using bulk milk urea concentration and temperature as explanatory variates. In common practice, emission reduction can be controlled by milk urea concentration. Animal nutritionists now have a tool to evaluate feeding strategies and dairy cow diets that are designed to reduce $\mathrm{NH}_{3}$ emissions.

The average bulk milk urea content in the Netherlands decreased from 30 to $25 \mathrm{mg} / 100 \mathrm{~g}$ of milk from 1998 to 2001. This indicates a reduction of emissions from dairy barns of about $12.5 \%$.

\section{ACKNOWLEDGMENTS}

This study was financed by the Dutch Ministry of Agriculture and Fisheries (Min. LNV) and the Dutch Dairy Product Board (PZ). The authors thank Gerard Verkade, Gerard de Bree, Henk Gunnink, Klaas Blanken, and Martin Wagemans for their work on the experimental farm. We thank Ad van Vuuren, Wim Scherphof, Pim Bruins, Albert Meijering, Paul Witlox, and Machiel Blok for their technical advice, and Pieter Vereijken for his help with the statistical analysis.

\section{REFERENCES}

Bannink, A., H. Valk, and A. M. van Vuuren. 1999. Intake and excretion of sodium, potassium and nitrogen and the effects on urine production by lactating dairy cows. J. Dairy Sci. 82:1008-1018. 
Ciszuk, P., and T. Gebregziabher. 1994. Milk urea as an estimate of urine nitrogen of dairy cows and goats. Acta Agric. Scand. 44:87-95.

CVB. 2002. Tabellenboek Veevoeding 2000 (Dutch Feeding Tables). Voedernormen landbouwhuisdieren en voederwaarde veevoeders (in Dutch). Central Bureau for Livestock Feeding, Lelystad, the Netherlands.

de Boer, I. J. M., M. C. J. Smits, H. Mollenhorst, G. van Duinkerken, and G. J. Monteny. 2002. Prediction of ammonia emission from dairy barns using feed characteristics. Part I: Relation between feed characteristics and urinary urea concentration. J. Dairy Sci. 85:3382-3388.

de Brabander, D., J. Vanacker, S. Botterman, J. de Boever, and Ch. Boucqué. 1999a. Influencing factors on milk urea concentration (in Dutch). Announcement DVV nr. 1108. Department Animal Nutrition and Animal Husbandry, Center for Agric. Research (CLO), Gent, Belgium.

de Brabander, D., S. Botterman, J. Vanacker, and Ch. Boucqué. 1999b. The milk urea concentration as indicator for nutrition and $\mathrm{N}$ excretion. Final conclusions and interpretations (in Dutch). Announcement DVV nr. 1109. Department Animal Nutrition and Animal Husbandry, Center for Agric. Research (CLO), Gent, Belgium.

de Jong, E. A. M., H. Klomp, G. Ellen, and H. van Hemert. 1992. Evaluation of a segmented-flow method for the routine determination of urea in milk. Neth. Milk Dairy J. 46:115.

DePeters, E. J., and J. D. Ferguson. 1992. Non protein nitrogen and protein distribution in the milk of cows. J. Dairy Sci. 75:31923209 .

Elzing, A., and G. J. Monteny. 1997. Modeling and experimental determination of ammonia emissions rates from a scale model dairy-cow house. Trans. ASAE 40:721-726.

Eriksson, L., and M. Valtonen. 1982. Renal urea handling in goats fed high and low protein diets. J. Dairy Sci. 65:385-389.

Genstat 5 Committee.1993. Genstat 5, release 3, Reference Manual. AFRC Institute of Arable Crops Research, Harpenden, UK. Oxford University Press, Oxford, UK.

Gonda, H. L., and J. E. Lindberg. 1994. Evaluation of dietary nitrogen utilization in dairy cows based on urea concentrations in blood, urine and milk, and on urinary concentration of purine derivatives. Acta Agric. Scand. 44:236-245.

Gustafsson, A. H., and D. L. Palmquist. 1993. Diurnal variation of rumen ammonia, serum urea, and milk urea in dairy cows at high and low yields. J. Dairy Sci. 76:475-484.

Hof, G., S. Tamminga, and P. J. Lenaers. 1994. Efficiency of protein utilization in dairy cows. Livest. Prod. Sci. 38:169.

Hof, G., M. D. Vervoorn, P. J. Lenaers, and S. Tamminga. 1997. Milk urea nitrogen as a tool to monitor the protein nutrition of dairy cows. J. Dairy Sci. 80:3333-3340.

LEI (Institute of Agricultural Economics). 1999. Agriculture, Economics and Environment 1999 (in Dutch), Institute of Agricultural Economics, The Hague, the Netherlands.

Meijer, R. G. M., G. J. Remmelink, and T. Boxem. 1996. OEB-level in dairy cow diets. Publication no. 116, Research Institute for Animal Husbandry, Lelystad, the Netherlands.

Mepham, T. B., P. Gaye, and J. C. Mercier. 1982. Biosynthesis of milk proteins. In Developments in Dairy Chemistry 1. Proteins. P. F. Fox, ed. Elsevier Sci. Publ., New York, NY.

Monteny, G. J. 2000. Modeling of ammonia emissions from dairy cow houses. Ph.D. Thesis, Wageningen Univ., the Netherlands.
Monteny, G. J., M. C. J. Smits, G. van Duinkerken, H. Mollenhorst, and I. J. M. de Boer. 2002. Prediction of ammonia emission from dairy barns using feed characteristics. Part II: Relation between urinary urea concentration and ammonia emission. J. Dairy Sci. 85:3389-3394.

Mugerwa, J. S., and H. R. Conrad. 1971. Relationship of dietary non protein nitrogen to urea kinetics in dairy cows. J. Nutr. 101:1331-1342.

Oltner, R., and H. Wiktorsson. 1983. Urea concentrations in milk and blood as influenced by feeding varying amounts of protein and energy to dairy cows. Livest. Prod. Sci. 10:457-467.

Pankratz, A. 1991. Forecasting with Dynamic Regression Models. Wiley \& Sons. New York, NY.

Sliggers, J. 2001. Towards sustainable levels for health and nature: Review document theme Acidification and Transboundary Air Pollution (in Dutch). Report VROM 010334/h/10-01 17529/187, Ministry of Housing, Spatial Planning and Environment (VROM), The Hague, the Netherlands.

Smits, M. C. J., H. Valk, A. Elzing, and A. Keen. 1995. Effect of protein nutrition on ammonia emission from a cubicle house for dairy cattle. Livest. Prod. Sci. 44:147-156.

Smits, M. C. J., H. Valk, G. J. Monteny, and A. M. van Vuuren. 1997. Effect of protein nutrition on ammonia emission from cow houses. Pages 101-107 in Gaseous Nitrogen Emissions from Grasslands. $\mathrm{CAB}$ International, Wallingford, UK.

Steenvoorden, J. H. A. M., W. J. Bruins, M. M. van Eerdt, M. W. Hoogeveen, N. Hoogervorst, J. F. M. Huijsmans, H. Leneman, H. G. van der Meer, G. J. Monteny, and F. J. de Ruijter. 1999. Monitoring of the national ammonia emission from agriculture: To an improved calculation method (in Dutch) Page 141 in Environmental Plan Bureau 6, Wageningen, the Netherlands.

Tamminga, S., W. M. van Straalen, A. P. J. Subnel, R. G. M. Meijer, A. Steg, C. J. G. Wever, and M. C. Blok. 1994. The Dutch protein evaluation system: The DVE/OEB system. Livest. Prod. Sci. 40:139-155.

Tilley, J. M., and R. A. Terry. 1963. A two-stage technique for the in vitro digestion of forage crops. J. Br. Grassl. Soc. 18:104-111.

van der Hoek, K. W. 2000. Basics of the manure and ammonia calculations 1997/1998 used for the Environmental Balance study 99 (in Dutch). National Institute of Public Health and the environment (RIVM), Bilthoven, the Netherlands.

van Duinkerken, G., G. André, M. C. J. Smits, G. J. Monteny, K. Blanken, M. J. M. Wagemans, and L. B. J. Šebek. 2003. Relation between diet and ammonia emission from the dairy cow barn (in Dutch). Applied Research Report nr. 25, Animal Sciences Group, Applied Research, Lelystad, the Netherlands.

van Es, A. J. H. 1975. Feed evaluation for dairy cows. Livest. Prod. Sci. 2:95-107.

van Es, A. J. H. 1978. Feed evaluation for ruminants. I. The systems in use from May 1978 onwards in the Netherlands. Livest. Prod. Sci. 5:331-345.

van Straalen, W. M. 1995. Modeling of nitrogen flow and excretion in dairy cows. Ph.D. Thesis, Wageningen University, Wageningen, the Netherlands.

van Vuuren, A. M. 1994. Digestion and nitrogen metabolism of grass fed dairy cows. Ph.D. Thesis, Wageningen University, Wageningen, the Netherlands.

van Vuuren, A. M., and S. Tamminga. 2001. Physiological basis for the minimum rumen degradable protein balance in dairy rations (in Dutch). CVB documentation report 28. Central Bureau for Livestock Feeding (CVB), Lelystad, the Netherlands. 